IPPeriodica Polytechnica

47(2), pp. 89-93, 2016

DOI: 10.3311/PPar.10335

Creative Commons Attribution (1)

RESEARCH ARTICLE

\section{Between Designer and Design: Parametric Design and Prototyping Considerations on Gaudís Sagrada Familia}

\author{
Rodrigo Makert ${ }^{1 *}$, Gilfranco Alves ${ }^{1}$
}

Received 28 November 2016

\begin{abstract}
Digital technologies have enabled new design methods, casting a reassessment of current theories of design. Rivka Oxman proposed five paradigmatic classes of digital design models according to the various relationships between the designer, conceptual content, applied design processes, and the design object. Kotnik states that catenary curve computational thinking is changing the way we think and design in architecture; it can be distinguished by three main levels of "computability": representational, parametric and algorithmic. Kolarevic clarifies that new digital approaches to design (based on computational concepts), construction and prototyping can be achieved by computerised numerical control process (CNC). The study aims to promote the integration of theory and practice in search of a feedback loop that promotes the scientific method of knowledge production. The theoretical work intends to develop an updated understanding of the use of digital technologies. The practical experimentation analyses the Sagrada Familia, designed by Antoni Gaudi, and proposes to compare digital (through the software Rhinoceros and the plug-in Grasshopper) and handmade physical models from the concept of catenary used by the Catalan architect. Referring to the Sagrada Familia, Burry believes that "the continued contribution of the craftsperson is judged as a crucial partner to the digital dialogue" (Burry, 2005)
\end{abstract}

\section{Keywords}

parametric design, prototyping, catenaries

${ }^{1}$ Course of Architecture and Urbanism,

Faculty of Engineering, Architecture and Urbanism and Geography

Federal University of Mato Grosso do Sul

Cidade Universitária, s/n, P.O.B. 549, CEP 79070-900,

Campo Grande, MS, Brazil

*Corresponding author, e-mail: rodrigomakert@hotmail.com

\section{Introduction}

This paper analyses the Expiatory Church of the Sagrada Família, designed by Antoni Gaudí in Barcelona, started at the end of the XIX century and still not completed. The objective is to investigate the theory and practice, from the design processes through to the parametric design thinking and digital fabrication. The catenary curve was chosen as an experiment in the digital and physical world.

Carpo states that the current logic for the project's idea presentation before Albert would be something like "if you can't draw what you have in mind in order to have others make it for you, you can still try to make it yourself" (Carpo, 2011). This seems to be the same logic used by Gaudí to design the Sagrada Família church. Therefore, this building is considered a paradigm in the digital fabrication field and a famous case study analysed by contemporary architects and digital designers. Gaudí developed his project through physical model making and frequently working in the construction field in a handmade way as, at that time, the architectural notations could not represent exactly what he intended.

Technology today allows ideas, as Gaudí's one for the Sagrada Família temple in Barcelona, to be represented through digital geometric models and to be used for pre-construction analysis. An example being prototypes created by 3D printers and polystyrene moulds in to fabricate special concrete parts (Gelani, 2011). In this process of digital fabrication, it is possible for the architect to have control of the final product without having to be subjected to serial production as used in the industrial mass production process (Alves and Pratschke, 2014).

Antoni Gaudí started to design architecture with parametric catenary curves and parametric hyperbolic paraboloids at the end of the nineteenth century. The use of parametric equations can be seen in many aspects of Gaudís architecture, but it is better illustrated through his use of his hanging chain model (Fig. 1).

Gaudí used this principle to design the Colònia Güell chapel, creating an upside-down model of the chapel using ropes loaded with weights. This way, because of "Hooke's law", the ropes will be always arranged in a way that results in pure compression. Thus, through changing the parameters in the parametric 
model, Gaudí could generate other versions of the Colònia Güell chapel and be sure that the resultant structure would be under pure compressive stress. Davis states that "this method of analogue computing was enlarged by Frei Otto to include, among other things, minimum surfaces derived from soap films and minimal paths found in wool dipped in liquid" (Davis, 2003). Nowadays, digital design is used by many architects who have been inspired by the experiments of Gaudí and Frei Otto.

This paper is structured in four parts: i) parametric modelling; ii) Gaudí, prototyping and digital fabrication; iii) a brief experiment involving physical and digital models through the study of the catenaries, and iv) conclusion.
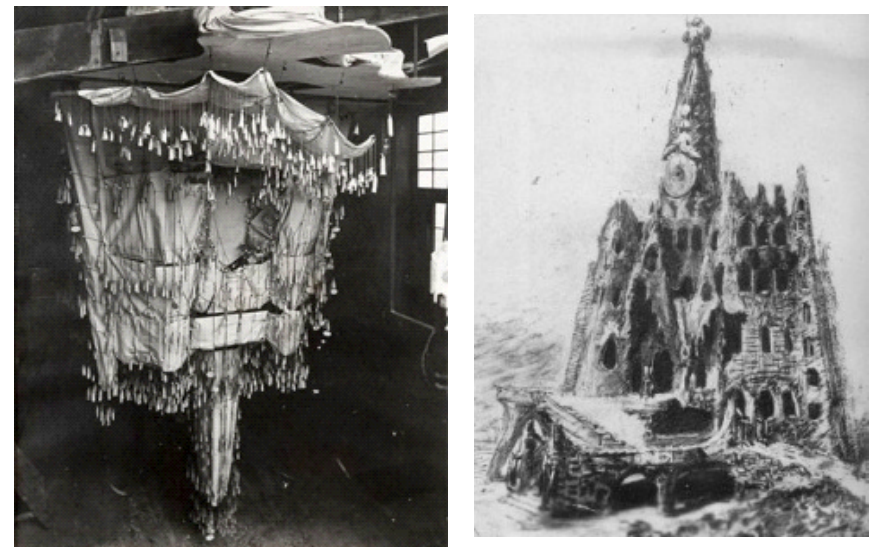

Fig. 1 Gaudí's hanging model and inverted photographs used to render forms (Maher and Burry, 2003)

\section{Parametric Modelling}

The objective of the integration of computers as tools for the design process is the potential for the conscious exploration of the elements that define a computable function as design tools. Therefore, digital design is about the interaction of formal process with architectural thinking. Kotnik states that computational thinking is changing the way we think and differentiates the architectural design process into three main levels of "computability": the representational, the parametric and the algorithmic (Kotnik, 2010).

If the generative process in the digital design is well formulated, it can potentially provide an analytical and structural framework that will, by itself, help to identify the elements, links, relationships, processes and properties of digital design. An example of this thesis is the taxonomy developed by Oxman. In an attempt to organize current design theories and methodologies, Rivka Oxman proposed five paradigmatic classes of digital design models according to various relationships between the designer, the conceptual content, the design process applied and the design object; these are : CAD models, formation models, generative models, the performance models and integrated compound models (Kotnik, 2010; Oxman, 2006).

All these definitions imply that the distinction between the three levels of design computability is not based on an assessment of the architectural quality of the resulting project, but on the level of understanding and maturity in the exploration of the computational nature of digital tools. This means that the levels are not about forms, but about ways of thinking that need to be seen as a digital skill (Kotnik, 2010). "In parametric architectures, the parameters of a particular design are declared, not its shape" (Kolarevic, 2001).

McCullough declares that the current capacity of the "digital architectures" to generate new projects is, in the same way, highly dependent on the designer's cognitive and perceptive skills; in the dynamic and continuous processes arises the emerging form. As noted by Burry, "the ability to define, determine and reconfigure geometrical relationships is of particular value" (Kolarevic, 2001).

Antoni Gaudí, as well as Frei Otto, found a simple way of using the catenary phenomenon in experimental models. According to the continuous load of its own weight in a connected chain between two points, there is the catenary curve the minimum energy state of the system (Fig. 2). The free forms of current architecture are difficult to control, but computational methods can help. Nowadays, it is possible that computational methods may replace the physical modelling by means of interactive simulation in a digital environment (Gruber, 2011).
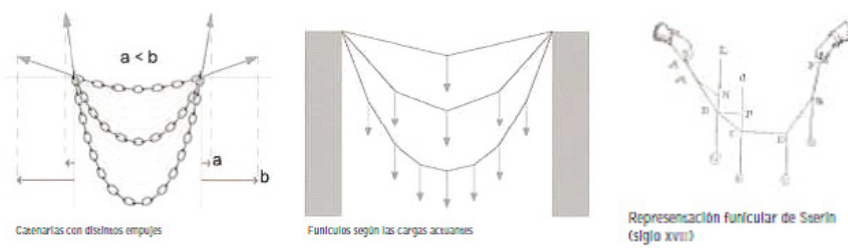

Fig. 2 Distinct catenaries and Sterin's funicular representation (XVII century) (Giralt-Miracle, 2002)

The method of computing the process that Antoni Gaudí and Frei Otto used in their experiments is known as "Analog Computing" (Kolarevic and Malkawi, 2005) or "Material computation" (Leach, 2009). Both the "optimised path systems" of Frei Otto and his team, as the modelling technique used by Gaudí for the Sagrada Família Church, experienced a material system for the calculation of the form (or form-finding) (Kolarevic and Malkavi, 2005). With the increasing use of computational methods, the natural processes can be digitally simulated in attempts to transfer the laws of physics or the dynamism of the processes in a digitally built environment (Gruber, 2011; Sheil, 2008).

Some contemporary architects are re-examining the works of Gaudí and Otto and found in them, sources of inspiration for research on the new morphogenetic generation of the search form, often connecting the lessons of analogue experimentation with more contemporary digital techniques. Mark Burry, as architectural consultant for the conclusion of Gaudí's Sagrada Família Church, has been exploring digital techniques to understand the logic of Gaudí (Leach, 2009). 


\section{Gaudí, prototyping e digital fabrication}

The digital processes of design associated with the possibilities of prototyping and digital fabrication allow the development of the construction methods, which are continually checked to develop the architectural design, as a sign of the project to be produced (Alves, 2014). This design process is currently being used in the Sagrada Família Church approximately one hundred years from its first design, and allows the continuity of its construction, even in collaborative mode (Burry, 2004).

Antoni Gaudí introduced a high level of geometric rationality for the Sagrada Família Church during the 43 years he conducted the project. The accuracy and application of its geometry, besides the drawings and models created by the architect, resulted in plentiful data for his successors to continue the project after his death in 1926 (Burry 2005; Burry et al., 2008). It is possible that the Sagrada Família is one of the first projects to adopt the most sophisticated digital tools and one of the first projects to transition to a post digital era as a conductor, "in circumstances where the continued contribution of the craftsperson is judged as a crucial partner for the digital dialogue" (Burry, 2004).

If you link theory and practice, scientific research and craftwork mastery, all the elements of the Sagrada Família are still a manufactory product, a research that, despite working with the latest technological tools, still complies with the working method of Gaudí. Due to the aspect of digital design, Burry, Grifoll and Serrano highlight in their book some construction and design elements of the Sagrada Família Church (such as columns, windows, domes, the roof of the main nave, sacristies and towers) with a digital design and fabrication approach in collaboration with the handmade design. The simulation and digital manipulation is used in many ways in the construction of the Sagrada Família Church (Fig. 3), for example, on the side window of the nave and adjusting the form of the nave's roof (the existing model made by Gaudí in 1:25 scale was digitally designed) (Burry et al., 2008).

According to Alves and Pratshke (Alves and Pratschke, 2014), the prototyping techniques and digital prototyping applied to architecture are very recent, when compared to the history of architecture itself. The digital era also radically reset the relationship between conception and production: it created a direct link between what can be designed and what can be built. Nowadays, the construction processes are not just digitally created, they can be built by "file-to-factory" processes through CNC fabrication technologies (Kolarevic, 2009). These processes change the focus of the representation compared to when it was carried out by hand. In programming the process, modelling objects and architectural elements like these improves the effectiveness of the process, however, it reduces the level of abstractions and interpretations.
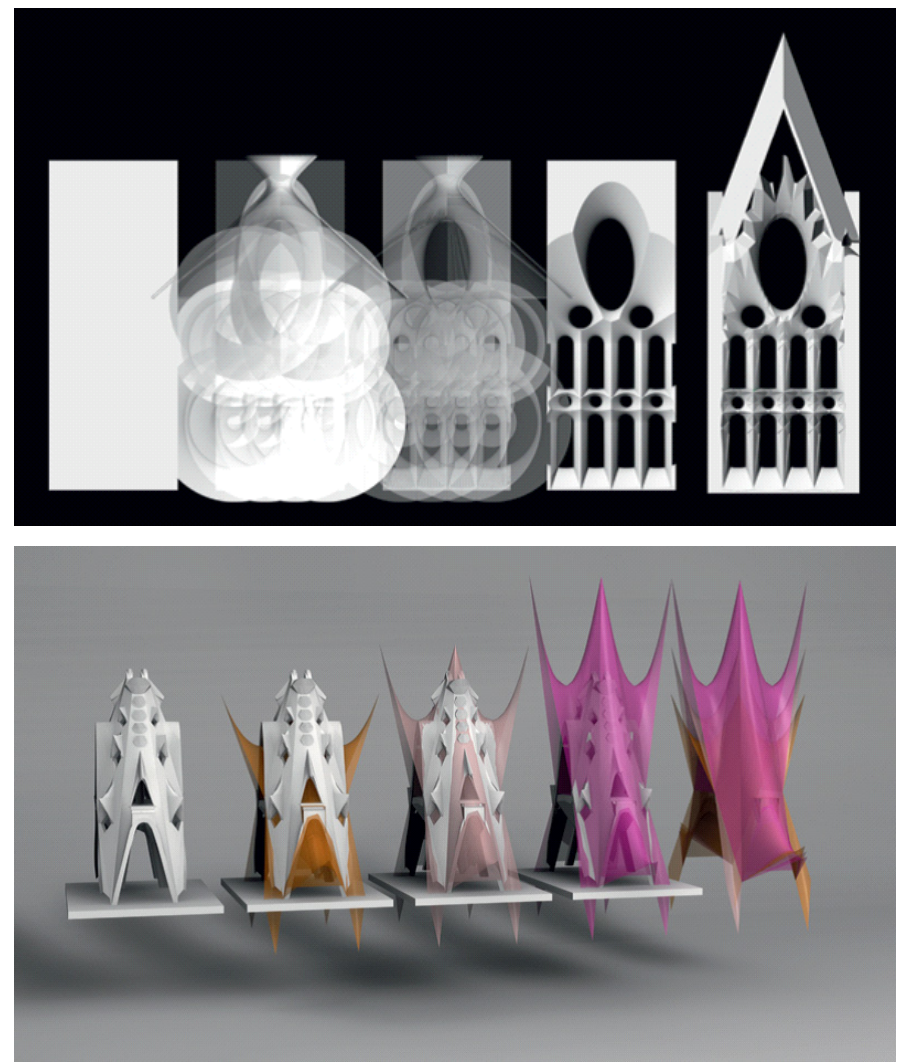

Fig. 3 On the left, the process of form generation for the side window of the nave in Sagrada Família Church. On the right, the nave's roof, finding the right combination of values for the virtual cover of hyperbolic paraboloids

(Burry et al., 2008)

\section{Catenary: a brief experiment with physical and digital models}

Inspired by Gaudí (Fig. 4), an experiment was conducted on a small scale simulating the hanging chain model in a physical environment (as Gaudí did in the beginning of the 20th century) and in a digital environment (as Burry does nowadays). The objective was to compare similar models, to see if the digital simulation can really simulate the physical environment. In exploring the difficulties and assessing the requirements, if the advantages outweigh the disadvantages, does the approach present a method that can be used by any architect today.

The physical experiment succeeded a series of attempts (Fig. 5). The first came from the use of a pre-defined grid which, resting on a wooden structure, proved inefficient compared to the experiments in Gaudís hanging chain. It was observed that the material and the nodes of the grid directly influenced the result. Using a continuous surface, delimited by lines in a square frame (equal to the digital model), presented a more stable behaviour than the first experiment, but it was difficult to handle the loads at specific points. Finally, the third model showed better handling and visualisation. Metal clips were used to build the 10x10grid anchored in the support structure. This was the closest to Gaudí's hanging chains experiment. 

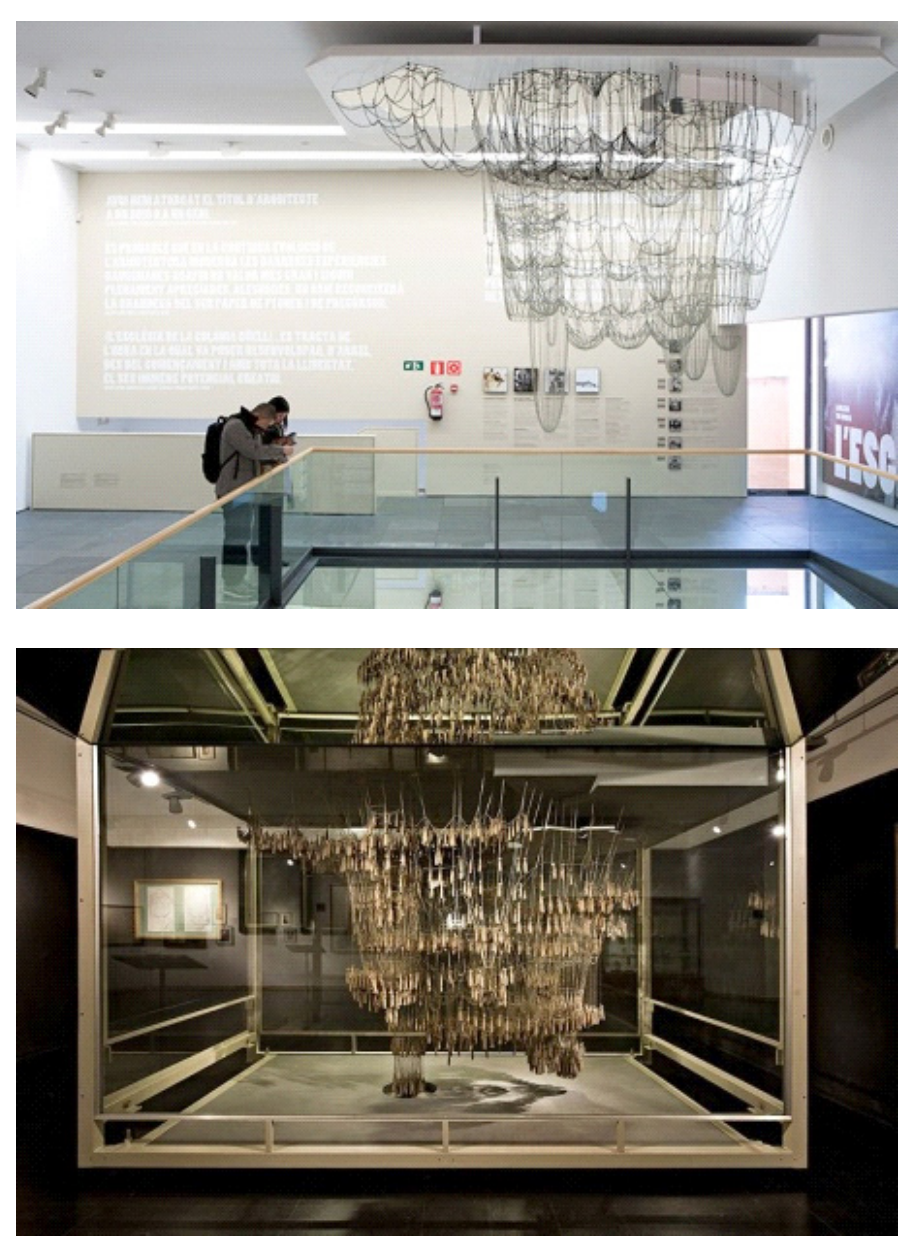

Fig. 4 A reproduction of the model designed by Gaudi in Colònia Güell' Exhibition and in Sagrada Família' Museum (Vidal 2013; Anon. 2011)

Mark West notes that a physical model is excellent because connected as in "current reality", it is qualitatively rich: full of dense information about the strengths and physical tensions. However, it is very difficult to obtain quantitative information on this type of model (Sheil, 2008).

The digital experiment used the Rhinoceros CAD software, the Grasshopper plug-in and the Kangaroo 2.0 particles simulator. It was essential that the experiment would enable a freedom, in a defined degree, to determine varying solutions according to the requirements of a particular project. Thus, a force is loaded on a vertex to compare the behaviour of the physical and the digital model. In a digital environment, there is no need to invert the model (Fig. 6).

As Woodbury, Williamson and Beesley observed, it requires some skill to handle the model created digitally, designing the data stream, dividing the process, and organising writing to ensure clarity and avoid redundancies (Woodbury et al., 2006). The greater the complexity of the project, the greater the code and problems to solve. This process can be described in different ways and the result can also vary according to design needs or the criteria and knowledge of the designer.
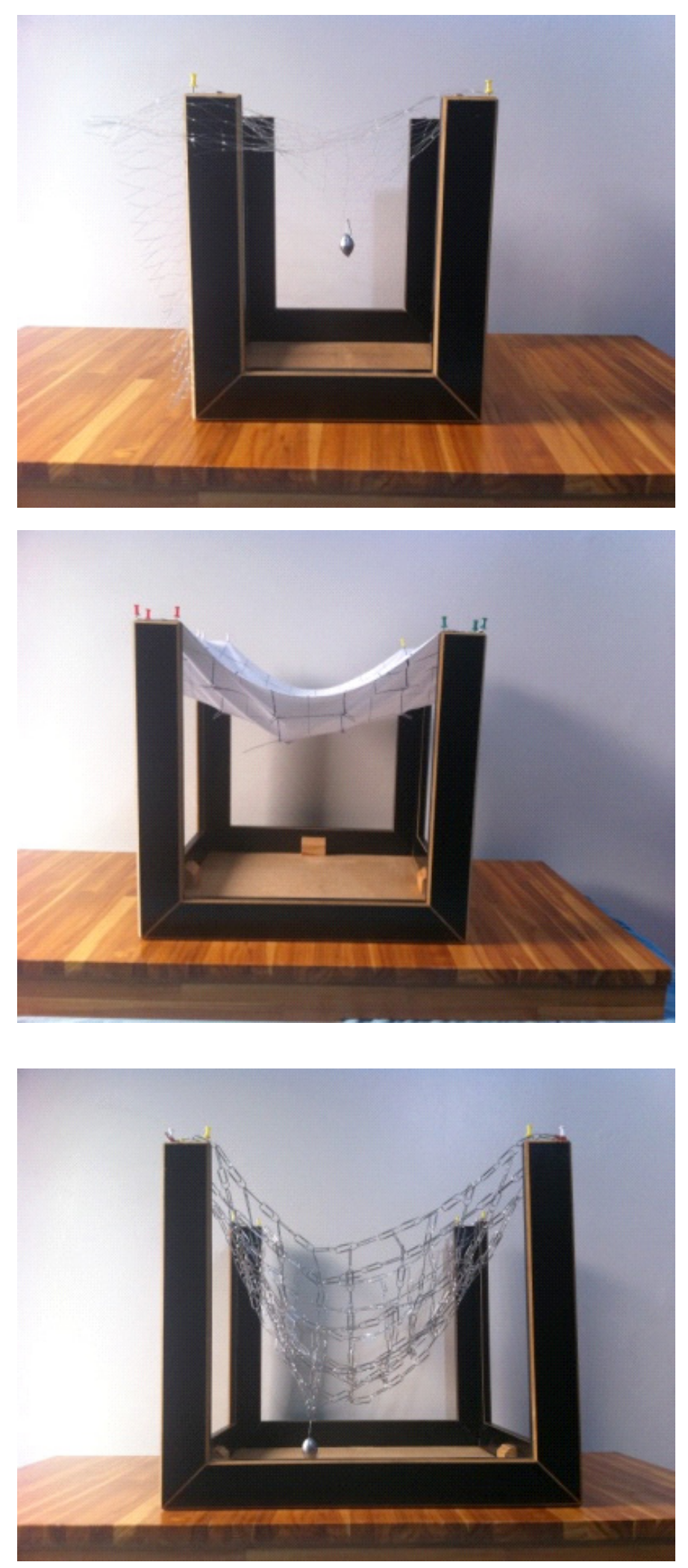

Fig. 5 Experiment performed with different meshes and using a weight to test their manipulation (Makert, 2015) 

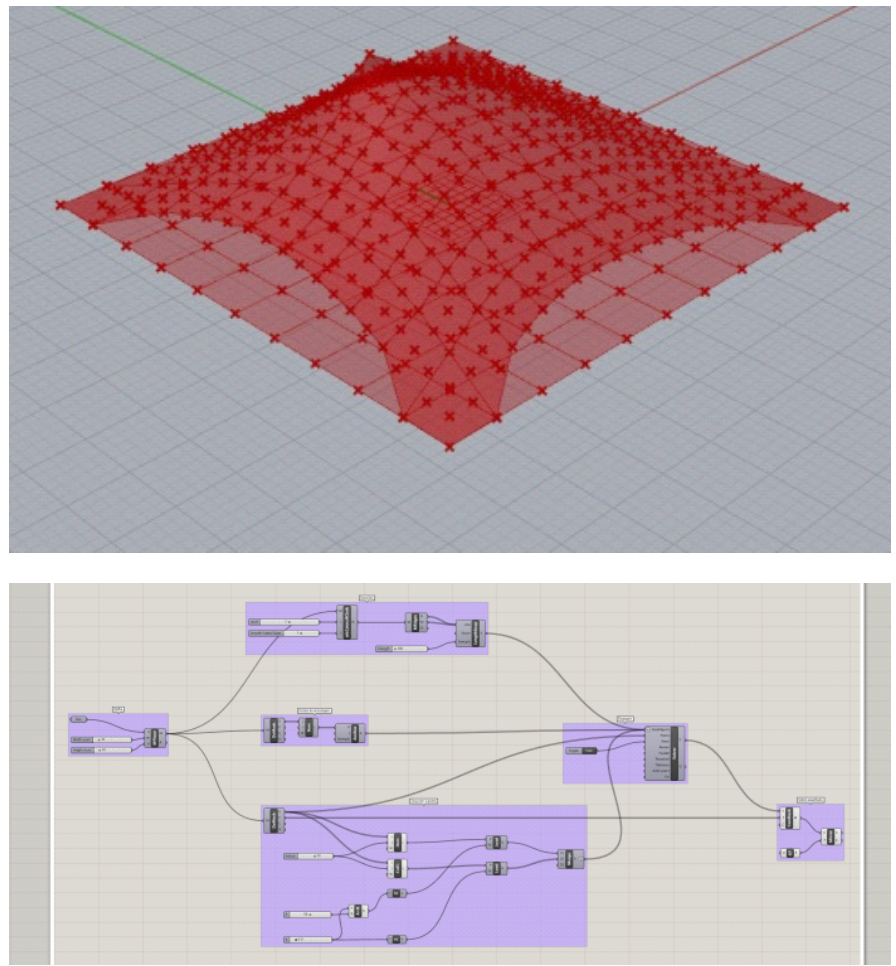

Fig. 6 The same 10x10 mesh created in a digital environment and the code made with Grasshopper plug-in (Makert, 2015)

\section{Conclusion}

Although its construction has been ongoing for more than a century, the Expiatory Church of the Sagrada Família needs today's most advanced technology to interpret and to build what Gaudí had in mind at his time. The empiricism met the genius and produced some of the most beautiful and intriguing architectural works. It is amazing that his works have ideological character, the expression of values and local identity even following a streamlined approach to thinking mathematically.

Through simple experiments, it was realised that digital manipulation also enables the manipulation of time itself. The digital process tends to be easier and faster to test and evaluate situations despite a complex initial understanding. Perhaps the biggest advantage is the simultaneous interaction between analysis, assessment and its direct application in design and the relative ease for change. The limited volume of experiments was faced with the difficulty of creating an object that could be easily manipulated.

Consequently, strategies, approaches and methods capable of causing a new displacement of professional practice were discussed. One that values experimentation (through simulations or algorithms that prioritise building performance), instead of mere Cartesian representation, in the development of the project; thus, incorporating an amount of information that would not be possible with the traditional method.

\section{References}

Alves, G. M. (2014). Cibersemiótica e Processos de Projeto: Metodologia em Revisão. $\mathrm{PhD}$ Thesis. Instituto de Arquitetura e Urbanismo. São Carlos, 2014. https://doi.org/10.11606/T.102.2014.tde-07012015-105828 (in Portuguese)

Alves, G., Pratschke, A. (2014). Punk Rock, Jogos e Processos Digitais de Projeto: Atitudes Proativas e Colaborativas para a Arquitetura do Século XXI. V!rus. 10. [Online]. Available from: http://www.nomads.usp.br/ virus/virus 10/?sec=6\&item $=1 \&$ lang=pt [Accessed: 22 nd June 2015] (in Portuguese)

Anon. (2011). Reproducció de la maqueta polifunicular de la Colònia Güell. Sagrada Família (Official). [JPG Image File Format]. Available from: http://www.sagradafamilia.org/en/museum/ [Accessed: 9th April 2016]

Burry, M. (2004). The Sagrada Família. In: Stacey, M. (ed.), Digital Fabricators. Coach House Press, Toronto.

Burry, M., (2005.) Homo Faber. Architectural Design. 75(4), pp. 30-37. https://doi.org/10.1002/ad.100

Burry, M.; Grifoll, J. C., Serrano, J. G. (2008). Sagrada Família s. XXI Gaudi Ara / Ahora / Now. Edicions UPC, Barcelona.

Carpo, M. (2011). The Alphabet and the Algorithm. MIT Press, Cambridge.

Celani, G. (2011). Lecture "Sistemas generativos de projeto e novos meios de produção pós-industrial”. In: Fab Lab SP - Fabricação digital, para quê e para quem?. FAU/USP. Available from: https:/www.youtube.com/

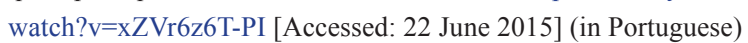

Davis, D. (2013). Modelled on Software Engineering: Flexible Parametric Models in the Practice of Architecture. PhD dissertation: RMIT University.

Giralt-Miracle, D. (2002). Gaudi: La Búsqueda de la Forma: Espacio, Geometria, Estructura y Construcción. Lunwerg Editores, Barcelona. 2002. (in Spanish)

Gruber, P. (2011). Biomimetics in Architecture: Architecture of Life and Buildings. Springer, Vienna. 2011. https://doi.org/10.1007/978-3-7091-0332-6

Kolarevic, B. (2001). Designing and Manufacturing Architecture in the Digital Age. In: Architectural Information Management: 19th eCAADe Conference Proceeding. pp. 117-123. eCAADe: Conferences. Helsinki, Finland. Helsinki University of Technology (HUT).

Kolarevic, B., Malkawi, A. M. (2005). Performative Architecture: Beyond Instrumentality. Spon Press, New York 2005.

Kolarevic, B. (2009). Architecture in the Digital Age: Design and Manufacturing. Taylor \& Francis e-Library, London. 2009.

Kotnik, T. (2010). Digital Architectural Design as Exploration of Computable Functions. International Journal of Architectural Computing. 8(1), p. 16.

Leach, N. (2009). Digital Morphogenesis. Architectural Design. 79(1), pp. 32 37. https://doi.org/10.1002/ad.806

Maher, A., Burry, M. (2003). The Parametric Bridge: Connecting Digital Design Techniques in Architecture and Engineering. In: Proceedings of the 2003 Annual Conference of the Association for Computer Aided Design in Architecture. Ball State University, Indianapolis, USA, Oct. 23-26, 2003, pp. 39-47.

Makert, R. (2015). Entre o Designer e o Design: Considerações sobre Processos Digitais de Projeto. UFMS, Campo Grande. (in Portuguese)

Oxman, R. (2006). Theory and design in the first digital age. Faculty of Architecture and Town Planning Technion, Haifa.

Sheil, B. (2008). Protoarchitecture: Between the Analogue and the Digital. Architectural Design. 78(4), pp. 6-11. https://doi.org/10.1002/ad.699

Vidal, M. L. (2013). Colònia Güell. [JPG Image File Format]. Available from: http://www.gaudicoloniaguell.org/en/what-visit/exhibition/ [Accessed: 9th April 2016]

Woodbury, R., Beesley, P., Williamson, R. (2006). Parametric Modelling as a Design Representational in Architecture: a process account. Canadian Design Engineering Network Conference, July 2006. Toronto 